\title{
The Effect of a Hand Massage on Pain and Depression in the Older People Living in a Nursing Home: Pilot Study
}

\author{
Huzurevinde Yaşayan Yaşılıara Uygulanan El Masajının \\ Ağrı ve Depresyona Etkisi: Pilot Çalışma
}

\author{
Saime EROL, ${ }^{1}$ Merve ERTUNC, ${ }^{2}$ Tugba OZTURK ${ }^{3}$
}

\begin{abstract}
SUMMARY
Objectives: This study was conducted to analyze the effect of a hand massage on pain and depression, blood pressure, pulse and respiration number in older people living in a nursing home.

Methods: The research was carried out using pre-post tests in a single-group quasi-experimental design and took place over the period from February to May 2013 in Istanbul. The study was conducted with 20 elderly individuals. The data for the study were collected with the "Questionnaire Form ", "McGill-Melzack Pain Questionnaire," and the "Geriatric Depression Scale." The hand massages were administered by the researchers according to the Kolcaba Hand Massage Protocol; the massage was given three days a week during six weeks, a total of 18 sessions, in the individual's room. The Wilcoxon and Friedman Tests were used in the evaluation.

Results: The age of the elderly individuals in the study was $79.00 \pm 6.24$ years. After the 18 sessions of hand massaging in the study, pain levels of the subjects $(p<0.001)$ and their depression scores $(p<0.01)$ displayed a significant decrease. In systolic blood pressure taken before, immediately after, and 30 minutes after, the massage exhibited a significant decrease after the first, third and sixth weeks in all of the readings $(p<0.001)$. Diastolic blood pressure values, pulse and respiration rates taken before, immediately after, and 30 minutes after, the massage exhibited significant decreases after the third and sixth weeks $(p<0.001)$.
\end{abstract}

Conclusion: It was concluded that hand massage is effective in reducing pain and depression scores in the elderly.

Key words: Pain; depression; hand massage; nursing home; older people.

1Department of Public Health Nursing, Marmara University, Health Sciences Faculty, Istanbul;

${ }^{2}$ Siyami Ersek Hospital, Istanbul;

${ }^{3}$ Arnavutkoy Public Hospital, Istanbul

Correspondence: Saime EROL, M.D.

e-mail: saimeerol@hotmail.com

Psikiyatri Hemşireliği Dergisi 2014;5(2):92-97

Journal of Psychiatric Nursing 2014;5(2):92-97

Doi: 10.5505/phd.2014.29292

Submitted: December 13, 2013 Accepted: June 15, 2014
$\ddot{O Z Z}$

Amaç: Bu araştırma, huzurevinde yaşayan yaşı bireylere uygulanan el masajının ağrı ve depresyona, kan basıncı, nabız ve solunum sayısına etkisini incelemek amacılla yapıldı.

Gereç ve Yöntem: Çalışma ön-son test, tek gruplu yarı deneysel araştırma tasarımı ile Istanbul'da Aile ve Sosyal Politikalar Bakanlığına bağı bir huzurevinde Aralık 2012-Mayıs 2013 tarihleri arasında yürütüldü. Araştırma katılmayı kabul eden toplam 20 yaşlı ile yürütüldü. Araştırmanın verileri, "Anket Formu", "McGill-Melzack Ağrı Formu" ve "Geriatrik Depresyon Ölçeği" kullanılarak toplandı. El masajı Kolcaba'nın El Masajı Protokolü’ne göre araştırmacılar tarafından haftada üç gün, altı hafta boyunca toplam 18 seans yaşlının odasında uygulandı. Verilerin değerlendirilmesinde Wilcoxon ve Friedman testi kullanıldı.

Bulgular: Çalışmada yaşlı bireylerin yaş ortalaması 79.00 6.24 bulundu. Onsekiz seans el masajı sonunda yaşılların ağrı düzeylerinde $(Z=3.207 ; p=0.001)$ ve depresyon puanlarında $(Z=2.46 ; p=0.01)$ istatistiksel olarak anlamlı bir azalma olduğu saptandı. Yaşlıların masaj uygulamasından önce, hemen sonra ve 30 dakika sonra alınan sistolik kan basıncında birinci, üçüncü ve altıncı haftalardaki tüm ölçümlerde istatistiksel olarak anlamlı azalma görüldü $(p<0.001)$. Yaşlıların diyastolik kan basıncı $(p<0.05)$, nabız $(p<0.001)$ ve solum sayısı ( $p<0.001)$ değerlerinde, masaj uygulamasından önce, hemen sonra ve 30 dakika sonrasındaki ölçümlerde üçüncü ve altıncı haftalar arasında istatistiksel anlamlı azalma görüldü.

Sonuç: El masajının yaşlıların ağrı ve depresyon puanlarını azaltmada etkili olduğu sonucuna varıldı.

Anabtar sözcïkler: Ağrl; depresyon; el masaji; huzurevi; yaşl birey.

\section{Introduction}

Specific health problems of older population's have rapidly increased especially in developed countries. Chronic diseases have occured, physical capabilities have decreased, cognitive functions and their daily routines have declined by aging. Pain prevalence has also increased in the elderly. Pain is a subjective experience that has different characteristics and intensities also, it negatively affects the life quality, physical functions and well-being of an old individual. ${ }^{[1]}$

According to the studies on the elderly living in nursing home, cronic pain prevalence ranged from $27 \%$ to $80 \%$, 
${ }^{[2,3]}$ the rates also change between $57.9 \%$ and $88.5 \%$ in our country. ${ }^{[4,5]}$

The reason of pain, which the elderly experience, can be depression or chronic pain may cause depression in the elderly. $30 \%-60 \%$ of people who are in pain are also experience depression. Thus, depression causes increase of pain. ${ }^{[5]}$

Depression prevalence in elderly living in nursing home is between $6,3 \%-48 \%,{ }^{[6,7]}$ while it is between $35.9 \%-76 \%$ in our country. ${ }^{[5,8,9]}$ When the researches are analyzed, the evidence show that pharmacological treatments for depression is efficient but not sufficient. ${ }^{[7,10]}$ Furthermore, adverse drug effects occur more often in the elderly due to polypharmacy. That occuring of adverse effects more often corroborates using nonpharmacologic methods for pain and depression treatments. ${ }^{[11]}$

Recently, in the controlling of pain non-pharmacological methods have been benefited to strenghten the effect of pharmocological methods and in the cases that pharmacological methods have been useless. Non-pharmacological methods imply the control pain using some methods but drugs. Among the advantages of these methods are easy to apply, not having adverse effects like analgesics and not being a burden for the individual. ${ }^{[12]}$

One of the non-pharmalogical methods are massage theraphy. Massage therapy have been utilized for many centuries by many different cultures. Massage is a technique which provides both mental and physical relaxation. It is direct form of non-verbal communication since it requires "touching". Furthermore; it supports the communication between the nurse and the old individual. ${ }^{[12-14]}$

Massage provides oxygenation of tissues increasing blood and lymph circulation; increases the secretion of endorphins; reduces the perception of pain, the level of anxiety, muscle cramps and sleep irregularities. Massage decreases blood pressure, pulse, respiration rates in the elderly by comforting of themselves. ${ }^{[15,16]}$

In a study named "Investigation of complemetary and alternative medicine practice and drug use in the elderly", conducted in our country with the elderly living at their homes, it has been identified that $54.3 \%$ of the elderly use either complemetary or alternative treatment methods. Also, 23.3\% of them use massage theraphy. When the reasons why they use complemetary or alternative methods have been investigated, it has been foud out that $17.4 \%$ of the elderly use these methods in order to reduce pain. ${ }^{[13]}$

In studies conducted in other countries with the elderly, it has been shown that rates of complementary and alternative medicine use ere between $28 \%$ and $50 \% .{ }^{[17,18]}$ Massage is one of the commonly utilized techniques as complementary or alternative methods. According to a research in England, $70 \%$ of complementary therapies used in palliative care includes massage. ${ }^{[19]}$

Literature supports that nurses can be authority at complementary therapies. ${ }^{[20]}$ Researches have proved that massage is an effective way to reduce depression and pain ${ }^{[16,21-23]}$ and back massage decreases blood pressure, pulse, respiration rates in the elderly by comforting of themselves. ${ }^{[16,21-25]}$

However, no research has been found in our country indicating the effect of a hand massage, given to elderly individuals living in nursing home, pain decrease and depressions.

Thus; present research has been conducted to analyze whether hand massage is useful for pain, depression, blood pressure, pulse and respiration counting.

\section{Materials and Methods}

The present study planned as a quasi-experimental study, having one-group, pre-post-tests design and it has been conducted at a nursing home over the period December 2012 - May 2013 in Istanbul. The sample of the study included 20 elderly volunteers living in the nursing home, complaining of pain for more than three months, scoring 18 and more from Mini Mental State, having no dementia and/or psychiatric problems, and no condition that would be a contraindication to providing hand massage.

The required data were collected by using the sociodemographic questionnaire form, the Geriatric Depression Scale (GDS), the McGill-Melzack Pain Questionnaire (MPQ) and Vital Signs Monitoring Form.

Sociodemographic Questionnaire Form: Includes six questions about the ages, genders, educational status, and chronic illnesses of the elderly participants.

Geriatric Depression Scale: The validity and reliability study for the Turkish version of the scale was carried out by Ertan in 1997. The accepted cutoff points were as follows: normal: 0-9 points, mild depression: 10-19 points, and severe depression: 20-30 points. ${ }^{[26]}$ Geriatric Depression Scale (GDS) Cronbach's alpha coefficient for this study was found as .88 .

Mc Gill - Melzack Pain Questionnaire: The validity and reliability of the questionnaire was carried out by Yazıc1, EtiAslan and Olgun (1998). Form consists of four sections; location of the pain, pain-time relation, pain level, observing characteristics of pain. Pain level is evaluated between 1 and 5. ${ }^{[27]}$

The tools have been applied, before the application of massge and after finishing of massage application (8 weeks), through interview technique.

Vital Signs Monitoring Form: Vital signs are recorded before, immediately after and 30 minutes after the massage. 


\section{The Procedure of the Research}

- The massages were applied three days a week during six weeks as 10 minutes per session in the individual's private room.

- The massages were applied in the most comfortable position at flexible hours. It was provided that the rooms were slient and had enough light.

- Almond oil was used as lubrican. Almond oil is a nourishing, fine textured oil, that lubricates without penetrating making it an ideal massage oil. It leaves the skin soft, smooth and moist without being too oily. It is an excellentr massage oil for all kind of skins. It can help to relieve itching, dryness and inflammation. It is obtained from the dried kernels of the almond tree. ${ }^{[28]}$

- The application was started with the same hand in each session. The massage was applied to the same elderly by the same researcher during 18 sessions.

- Vital signs were recorded before, immediately after, and 30 minutes after the massage.

- The pulse was always taken from radial artery of the hand that the first massage applied during (one) minute when the elderly were in sitting position. The manual sphygmomanometer was calibrated for the blood pressure readings before helding the research. The blood pressure was always taken from the arm that the first massage applied when the elderly were in sitting position. The respiratory rates were counted by the researcher observing the elderly's rib cage movements when she/he was breathing during (one) minute. This phase was not explained to the elderly in order not to cause a change in their respiratory rates.

\section{Protocol for Hand and Wrist Massage}

\section{Introduction}

- All strokes are repeated three times. Each hand is massaged for (five - eight) minutes.

- Therapeutic rapport is established. Explain the procedure and request the elderly to report any sensations that are not comfortable to him or her as you massage the hand.

- Place the elderly's hand in a palm-up position with thumb abducted. The nurse collects a small amount of lubricant in his or her hand and rubs the hands.

\section{Procedure for Palm}

- The nurse's right hand supports the hand of the elderly. Using the left thumb of left hand, the nurse strokes up from thenar towards wrist. While the thumb squeezes at the wrist, other fingers massages at dorsal surface.

Reposition hands to have the nurse's left hand support the elderly's hand. Using the right hand's thumb, the nurse strokes up to joints and palm. Other fingers massages at dorsal surface. Than the thumb squeezes at the wrist.

- Reposition hands to have the nurse's hand support the elderly's hand. Using the left hand's thumb massages from the metacarpophalangeal joints to the wrist with back and forth.

The thumb kneades in small circles over the same areas, returns with a superficial stroke after each movement. Pressure is gentle and adjusted to the comfort of elderly.

- The entire palm surface of the hand is massaged with light, circular strokes. Before massaging the dorsal surface of the hand, stroke lightly with several long motions toward the heart.

\section{Procedure for Dorsal Side}

- Turn the client's hand palm down. The nurse's left hand supports the elderly's hand of the elderly. With the thumb of right hand, the nurse strokes in the spaces between the metacarpals, with direct pressure toward the tissue forming the spaces between the bones in the back of the hand. Supporting the hand, massage all surfaces of each finger and the

Table 1. Descriptive characteristics of the elderly

\begin{tabular}{lcc}
\hline Variables & $\mathrm{n}$ & $\%$ \\
\hline The mean of age & \multicolumn{2}{c}{$79.00 \pm 6.24$} \\
Age group (years) & \multicolumn{1}{c}{} \\
$\quad 65-74$ & 6 & 30.0 \\
$75-84$ & 5 & 45.0 \\
$\quad 85-94$ & & 25.0 \\
Gender & 15 & 75.0 \\
$\quad$ Female & 5 & 25.0 \\
$\quad$ Male & & \\
Education Level & 1 & 5.0 \\
$\quad$ Illiterate & 2 & 10.0 \\
$\quad$ Literate & 11 & 55.0 \\
$\quad$ Primary school graduate & 4 & 20.0 \\
$\quad$ High school graduate & 2 & 10,0 \\
$\quad$ Degree and above & & \\
Chronic Illness & & \\
$\quad$ Yes & 19 & 95.0 \\
$\quad$ No & 1 & 5.0 \\
Total & 20 & 100.0 \\
\hline
\end{tabular}

Table 2. Effect of massage on pain and depression $(n=20)$

\begin{tabular}{|c|c|c|c|c|}
\hline & \multirow[b]{2}{*}{ Mean } & \multirow[b]{2}{*}{ Std. } & \multicolumn{2}{|c|}{ Statistics } \\
\hline & & & $\mathrm{Z}^{*}$ & $p$ \\
\hline \multicolumn{5}{|l|}{ Pain } \\
\hline Before & 3.40 & 0.75 & 3.207 & 0.001 \\
\hline After & 2.80 & 0.89 & & \\
\hline \multicolumn{5}{|l|}{ Depression } \\
\hline Before & 13.00 & 6.98 & 2.46 & 0.01 \\
\hline After & 11.40 & 6.80 & & \\
\hline
\end{tabular}


thumb, starting at the point where the finger connects to the palm and move toward the tip if the finger.

- Finish the massage by stroking the surface of the hand, wrist to fingertip with a light stroke (three) times. ${ }^{[29]}$

Written permission to conduct the study was obtained from the nursing home's administration office and Marmara University Institute of Health Sciences Ethics Committee. Informed consent forms have been signed by the elderly to participate in research.

For the comparison of pain and depression scores before and after the massage, Wilcoxon test was utilized. Friedman Tests were used to compare vital signs before, immediately after, and 30 minutes after the massage. The results have been assessed as $95 \%$ reliability, $\mathrm{p}<0.05$ significance and $\mathrm{p}<0.01$ $\mathrm{p}<0.001$ advanced significance level.

\section{Results}

The mean age of the participants were $79.00 \pm 6.24$ ( $\min =65$, max=94). $75.0 \%$ of the elderly people were female and $25.0 \%$ were male. $10.0 \%$ of the elderly people had Bachelor's degree. $95.0 \%$ of them had a chronic illness (hypertension, diabetes, rheumatoid arthritis, ets..) (Table 1).

When pain sides were examined; $30.0 \%$ of the elderly had headache, 35.0\% neck, 30.0\%'s shoulder, 25.0\%'s back, 35.0\%'s waist, 55.0\%'s arm, \% 55.0's leg, \% 35.0's foot pain. When pain was analyzed in relation to time; it was found out that $50.0 \%$ permenant, $45.0 \%$ periodic, $5.0 \%$ 's of them expe- rience instantaneous pain. Furthermore, the 20\%'s of them were practicing massage; $5.0 \%$ 's hot application, $10.0 \%$ 's cold application and 45.0\%'s of them rest to remove pain.

While the average intensity of pain of the elderly in premassage was 3.40 out of 5 , it decreased to 2.80 after the massage. This decrease in pain was statistically significant $(Z=3.207, p=0.001)$. While the mean depression score in pre-massage phase was 13.0, after the massage it decreased to 11.40 . This decrease in depression score was statistically significant $(\mathrm{Z}=2: 46, \mathrm{p}=0.01)$ (Table 2$)$.

After comparing three times, systolic blood pressure was significantly decreased in contrast to pre-massage (respectively: $\mathrm{kwx}^{2}=22: 55, \mathrm{p}=0.000, \mathrm{x}^{2}=26.31, \mathrm{p}=0.000, \mathrm{kwx}^{2}=27.79$, $\mathrm{p}=0.000$ ).

There was no a significant decrease in diastolic blood pressure during the first week after the massage $(p>0.05)$, but the third and sixth weeks showed a significant decrease (respectively, $\mathrm{kwx}^{2}=12: 45, \mathrm{p}=0.002, \mathrm{kwx}^{2}=23: 45, \mathrm{p}=0.000$ ).

While a statistically significant decrease wasn't observed in the pulse rate after massage during the first week ( $p>0.05)$, following the third and sixth weeks a significant decrease was recorded $\left(\mathrm{kwx}^{2}=5.20, \mathrm{p}=0.002, \mathrm{kwx}^{2}=21.94, \mathrm{p}=0.000\right)$.

There was not any significant decrease in respiratory rates during the first week after the massage ( $p>0.05)$, however the third and sixth weeks showed a statistically significant decrease (respectively: $\mathrm{kwx}^{2}=23.04, \mathrm{p}=0.002, \mathrm{kwx}^{2}=24.75$, $\mathrm{p}=0.000)$ (Table 3).

Table 3. Effect of massage on vital signs $(n=20)$

\begin{tabular}{|c|c|c|c|c|}
\hline Vital signs & Massage & Week 1 & Week 3 & Week 6 \\
\hline \multirow[t]{3}{*}{ Systolic blood pressure } & Before & $130.85 \pm 12.57$ & $134.95 \pm 10.40$ & $132.95 \pm 10.43$ \\
\hline & After & $124.45 \pm 11.17$ & $128.35 \pm 9.64$ & $127.45 \pm 9.78$ \\
\hline & After 30 minute & $125.40 \pm 9.84$ & $127.60 \pm 9.56$ & $127.80 \pm 9.44$ \\
\hline \multirow[t]{2}{*}{ Statistics } & $x^{2 *}$ & 22.55 & 26.31 & 27.79 \\
\hline & $\mathrm{p}$ & 0.000 & 0.000 & 0.000 \\
\hline \multicolumn{5}{|l|}{ Diastolic blood } \\
\hline \multirow[t]{3}{*}{ Pressure } & Before & $75.80 \pm 7.71$ & $78.85 \pm 5.61$ & $79.90 \pm 5.00$ \\
\hline & After & $71.90 \pm 5.68$ & $74.75 \pm 6.45$ & $75.10 \pm 3.98$ \\
\hline & After 30 minute & $72.40 \pm 5.32$ & $75.40 \pm 4.95$ & $74.05 \pm 4.34$ \\
\hline \multirow[t]{2}{*}{ Statistics } & $x^{2 *}$ & 8.63 & 12.45 & 23.45 \\
\hline & $\mathrm{p}$ & 0.13 & 0.002 & 0.001 \\
\hline \multicolumn{5}{|l|}{ Pulse } \\
\hline & Before & $83.05 \pm 8.86$ & $84.25 \pm 7.60$ & $84.25 \pm 6.81$ \\
\hline & After & $78.40 \pm 9.04$ & $79.00 \pm 7.85$ & $79.25 \pm 6.71$ \\
\hline & After 30 minute & $78.85 \pm 7.72$ & $79.80 \pm 7.14$ & $78.65 \pm 6.46$ \\
\hline \multirow[t]{2}{*}{ Statistics } & $x^{2 *}$ & 8.02 & 20.05 & 21.94 \\
\hline & $\mathrm{p}$ & 0.18 & 0.00 & 0.00 \\
\hline \multirow[t]{3}{*}{ Respiratory } & Before & $20.95 \pm 2.48$ & $21.15 \pm 1.18$ & $21.35 \pm 1.63$ \\
\hline & After & $19.85 \pm 1.69$ & $19.90 \pm 1.07$ & $19.55 \pm 1.73$ \\
\hline & After 30 minute & $20.20 \pm 1.23$ & $19.60 \pm 0.99$ & $19.60 \pm 1.04$ \\
\hline \multirow[t]{2}{*}{ Statistics } & $x^{2 *}$ & 6.71 & 23.04 & 24.75 \\
\hline & $\mathrm{p}$ & 0.35 & 0.00 & 0.00 \\
\hline
\end{tabular}

${ }^{*} x^{2}$ : Friedman Tests. $p>0.05, p<0.05, p<0.01, p<0.0001$. 


\section{Discussion}

As a result of the present study, it was stated that the hand massage applied three times a week during six weeks was effective on reducing pain level and depression rates for the elderly. There was a significant decrease in the levels of both systolic and diastolic blood pressure, pulse and respiratory rates.

Similar to these results, Chang (2008) applied a hand massage with aromatherapy to 58 old people living in hospice dividing them into two groups as experimental $(\mathrm{n}=28)$ and control group $(n=30)$ for (five) minutes per session during (seven) days. At the end of the study, a significant decrease in both depression and pain ratesof the elderly in experimental group has been identified. ${ }^{[16]}$

In addition, Mok and Woob (2004) applied back massage to paralytic people for 10 minutes per session during (seven) days to prove the effect of massage on pain and depression. They determined the rates were certainly lower on the third day of the experiment than they were at the beginning of the experiment. ${ }^{[21]}$ Similar to the previous experiment, that was held with paralytic people, the pain rates were decreased in the session of Choi's study. ${ }^{[22]}$ Cassileth and Vickers also divided 1290 cancer patients into three groups and applied the Swedish massage to the first group, low pressure massage to the second group, foot massage to the third group. They also determined the pain rates of every group have decreased. ${ }^{[23]}$

As shown above, depression level got low due to hand massage. Similar to research of our study, depression rate was reduced by Choi's massage with aromatherapy on the old women who had osteoarthritis. ${ }^{[22]}$

According to results of the our study except body temperature, vital symptoms of elderly decreased 15 minutes after hand massage. Çinar and Eser (2009) showed that vital symptoms except body temperature reduced by back massage applied on elderly. They got the values of various symptoms respectively after the massage, 15 and 30 minutes later. ${ }^{[24]}$ Holland and Pokorny (2001) determined that there was a decrease in both of systolic and diastolic blood pressure thanks to light lack massage on the elderly. They also realized there was decrease in pulse and respiration rates. ${ }^{[25]}$ Furthermore, Mok and Woob applied back massage on 102 paralytic patients for 10 minutes per session during (seven) days. At the end of study, they observed that blood pressure and pulse rates reduced after massage and (three) days later the massage. ${ }^{[21]}$ In those three studies, it was stated that vital symptoms reduced by back massage. Our study proved hand massage is effective in reducing vital symptoms as well.

However, the results could be due to factors other than hand massage, such as performing physical contact with another, company and conversation. The older people may have answered the questions more positively to please the researchers who apply them hand massages or to express gratitude. To exclude those factors, a controlintervention which includes holding the hand of the older people for the same duration to give massage would be considered.

It is a widely known fact that massage reduces muscle tension and ensures relaxation. So, how does the hand massge reduce pain?

In 1962, Ron Melzack and Patrick Duvar discussed "Gate Control Theory" in order to explain how pain works. They put forth that when you massage the injured part of your body, you send a message to your brain hindering your pain. So that, thanks to massage, pain is perceived something better by the brain. Massage behaves like an analgesic and inhibits the pain signs that are sent to brain. Moreover; massage is considered to help the body release of analgesics like pioid or endorphin that are natural-products of the body. ${ }^{[30]}$

\section{Conclusions and Recommendations}

It was confirmed through our study that hand massage applied on old people for 10 minutes three days a week during (six) weeks is effective in;

- reducing pain rate,

- declining of depression scores.

Diastolic pressure, systolic pressure, pulse and respiration rates reduced gradually after massage and 30 minutes after that, comparing to the beginning of study.

Applying hand massage is recommended to the nurses and the physiotherapists working in nursing homes to manage reduce of pain and depression rate using the hand massage protocols.

A broader study with randomisation to a control group and with a control intervention is recommended.

To sum up, it might be more reliable if the result of vital symptoms in our study should be assessed by other people than our researchers.

\section{References}

1. Tanrıverdi G, Okanlı A, Cetin H, Ozyazıcıoglu N, et al. Pain in the elderly populatıon. Turkish Journal of Geriatrics 2009;12:190-7.

2. Smalbrugge $M$, Jongenelis $K L$, Pot MA, Beekman TFA, et al. Pain among nursing home patients in the Netherlands: Prevalence, course, clinical correlates, recognition and analgesic treatment - an observational cohort study. BMC Geriatr 2007;7:1-9.

3. Boerlage $A A$, van Dijk $M$, Stronks $D L$, de Wit $R$, et al. Pain prevalence and characteristics in three Dutch residential homes. Eur J Pain 2008;12:910-6.

4. Babacan Gümüş A, Keskin G, Orgun F. Huzurevinde yaşayan yaşlılarda ağrı ve yaşam aktiviteleri: Depresyon, anksiyete ve somatizasyon yönünden bir inceleme. (Pain and living activities in elderly at a nursıng home: an investigation in terms of depression, anxiety and somatization) Turkish Journal of Geriatrics 2012;15:299-305.

5. Yıldız A, Erol S, Ergün A. Bir huzurevinde kalan yaşlılarda ağrı ve depresyon 
riski. (Pain and depression risk among elderly people living in a nursing home.) Turkish Journal of Geriatrics 2009;12:156-64.

6. Sherina M, S. Rampal L, Aini MM, Norhidayati H. The prevalence of depression among elderly in an urban area of Selangor, Malaysia. The International Medical Journal 2005;4:57-63.

7. Levin CA, Wei W, Akincigil A, Lucas JA, et al. Prevalence and treatment of diagnosed depression among elderly nursing home residents in Ohio. $J$ Am Med Dir Assoc 2007;8:585-94.

8. Demet MM, Taşkın O, Deniz F, Karaca N, İçelli İ. Manisa huzurevlerinde kalan yaşılıarda depresyon belirtilerinin yaygınlığı ve ilişkili risk etkenleri. (Depressive Symptomatology Among Elderly Residential Home Residents in Manisa: Prevalence and Related Risk Factors). Türk Psikiyatri Dergisi 2002;13:290-9.

9. Bahar A, Tutkun $\mathrm{H}$, Sertbaş $\mathrm{G}$. Huzurevinde yaşayan yaşlıların anksiyete ve depresyon düzeylerinin belirlenmesi. (The determination of the level of anxiety and depression of old people who live in the nursing home ). Anadolu Psikiyatri Dergisi 2005;6:227-39.

10. Oestergaard S, Møldrup C. Improving outcomes for patients with depression by enhancing antidepressant therapy with non-pharmacological interventions: a systematic review of reviews. Public Health. 2011;125:35767.

11. Kutsal Gökçe Y. Yaşlılarda çoklu ilaç kullanımı. (Polypharmacy in elderly). Turkish Journal of Geriatrics (Özel Sayı) 2006;37-44.

12. Shrestha S. Patricia S. Devkota R. A critical literature review on non-pharmacological approaches used by older people in chronic pain management. Indian Journal of Gerontology 2013;27:135-61.

13. Dedeli Ö. Karadovan A. Yaşlı bireylerde ilaç kullanımı ve tamamlayııı alternatif tedavi uygulamalarının incelenmesi. (Investigation of complementary and alternative medicine practice and drug use in the elderly) Spatula DD 2011;1:23-32.

14. Özer S. Akyürek B. Başbakkal Z. Hemşirelerin ağrı ile ilgili bilgi, davranış ve klinik karar verme yeteneklerinin incelenmesi. (Investigation of nurses' pain related knowledge, attitude and clinical decision making skills). Ağrı 2006;18:36-43.

15. Snyder M, Wieland J. Complementary and alternative therapies: what is their place in the management of chronic pain? Nurs Clin North Am 2003;38:495-508.
16. Chang SY. Effects of aroma hand massage on pain, state anxiety and depression in hospice patients with terminal cancer. [Article in Korean] Taehan Kanho Hakhoe Chi 2008;38:493-502. [Abstract]

17. Kaboli PJ, Doebbeling BN, Saag KG, Rosenthal GE. Use of complementary and alternative medicine by older patients with arthritis: a populationbased study. Arthritis Rheum 2001;45:398-403.

18. Running A, Shreffler-Grant J, Andrews W. A Survey of Hospices Use of Complementary Therapy. J Hosp Palliat Nurs 2008;10:304-312.

19. Gray RA. The use of massage therapy in palliative care. Complement Ther Nurs Midwifery 2000;6:77-82.

20. Turan N, Öztürk A, Kaya N. Hemşirelikte yeni bir sorumluluk alanı: Tamamlayııı terapi. Maltepe Üniversitesi Hemşirelik Bilim ve Sanatı Dergisi 2010;3:93-8.

21. Mok E, Woo CP. The effects of slow-stroke back massage on anxiety and shoulder pain in elderly stroke patients. Complement Ther Nurs Midwifery 2004;10:209-16.

22. Choi IR. Effects of aroma therapy massage on pain, physical function, sleep disturbance and depression in elderly women with osteoarthritis. Korean J Women Health Nurs 2006;12:168-76.

23. Cassileth BR, Vickers AJ. Massage therapy for symptom control: outcome study at a major cancer center. J Pain Symptom Manage 2004;28:244-9.

24. Çınar Ş, Eşer I, Khorshid L. The effects of back massage on the vital signs and anxiety level of elderly staying in a rest home. Hacettepe Üniversitesi Sağlık Bilimleri Fakültesi Hemşirelik Dergisi 2009;16:14-21.

25. Holland B, Pokorny ME. Slow stroke back massage: its effect on patients in a rehabilitation setting. Rehabil Nurs 2001;26:182-6.

26. Ertan T, Eker E. Reliability, validity, and factor structure of the geriatric depression scale in Turkish elderly: are there different factor structures for different cultures? Int Psychogeriatr 2000;12:163-72.

27. Eti-Aslan F. Ağrı değerlendirme yöntemleri. C.Ü. Hemşirelik Yüksekokulu Dergisi 2002;6:9-16.

28. Almond oil for skin. http://www.newhealthguide.org/Almond-Oil-ForSkin.html Access Date:07-03.2014.

29. Kolcaba K, Schirm V, Steiner R. Effects of hand massage on comfort of nursing home residents. Geriatr Nurs 2006;27:85-91.

30. Melzack R, Wall PD. Pain mechanisms: a new theory. Science 1965;150:9719. 